\title{
SPATIAL AND TEMPoral VARIATION IN THE PRESENT AND Historical SEDimentaRY Organic Mat'ter Within the Río de la Plata Estuary (South AMERICA) IN RELATION TO THE SALINITY/TURBIDITY GRADIENT
}

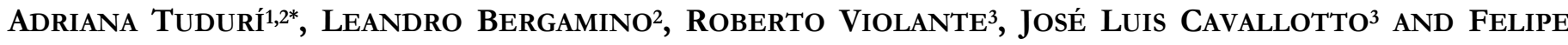 \\ GARCÍA-RODRÍGUEZ2,4
}

1 Universidad de la República, Facultad de Ciencias, Sección Oceanografía y Ecología Marina, Montevideo, Uruguay

2 Universidad de la República, Centro Universitario Regional Este (CURE), Rocha, Uruguay

3 Servicio de Hidrografía Naval. Buenos Aires, Argentina

4 Universidade Federal do Rio Grande, Instituto de Oceanografia, Programa de Pós-Graduação em Oceanografia Física, Química e Geológica, Rio Grande, Brazil

* Corresponding author, adri.tuduri@gmail.com

Received on 21 September 2018

Received in revised form on 13 December 2018

Accepted on 14 December 2018

Editor: Leticia Burone, Universidad de la República, Uruguai
Citation:

Tudurí, A., Bergamino, L., Violante, R., Cavallotto, J.l., García-Rodríguez, F., 2018. Spatial and temporal variation in the present and historical sedimentary organic matter within the Río de la Plata Estuary (South America) in relation to the salinity/turbidity gradient. Journal of Sedimentary Environments, 3 (4): 265-279.

\section{Abstract}

The aim of this study is to examine sedimentary organic matter sources, spatial distribution and temporal variability in a large estuarine system, the Río de la Plata estuary (South America). For this purpose, this work integrates recent and historical carbon and nitrogen isotopes $\left(\delta^{13} \mathrm{C}, \delta^{15} \mathrm{~N}\right)$, total organic carbon, total nitrogen, $\mathrm{C} / \mathrm{N}$ ratios and sediment grain size analyses along the Río de la Plata estuary. Principal component analysis based on geochemical variables and salinity revealed two main biogeochemical contrasting zones, corresponding to the upper and the lower estuary. Such zones are derived from the density gradient observed at the maximum turbidity zone acting as a physical barrier by trapping fine sediments and controlling primary productivity. As a consequence, sedimentary total organic carbon and total nitrogen increase from upper reaches towards lower reaches to attain maximum values under the turbidity gradient due to the presence of fine sediments. On the other hand, $\mathrm{C} / \mathrm{N}$ ratios display an opposite trend, with higher values in the

\section{Introduction}

Estuaries are among the most diverse and productive marine environments in the world, as they assimilate and process most of the river discharges and coastal basins (Paerl, 2006; Bianchi, 2007; Canuel and Hardison, 2016). upper reaches due to a higher influence of continental organic matter. Moreover, Stable Isotope Analysis in R (SIAR) based on $\delta^{13} \mathrm{C}$ and $\delta^{15} \mathrm{~N}$ reveals that the main organic matter source to the sediment appears to be the continental particulate organic matter and the estimated percentages of terrestrial allochthonous contribution (C3 plants) indicated a decreased contribution towards the lower reaches. The paleoenvironmental analysis shows a change in the sedimentary organic matter composition since 1970 associated to an increased influence of terrestrial organic matter. This trend is related to an increase in the Paraná River flow, which in turn is related to climatic variability (i.e., the polarity change of the Pacific Decadal Oscillation).

Keywords: Stable isotopes. Sediment deposits. Pacific Decadal Oscillation. Hydrodynamic. Historical reconstruction. Maximum turbidity zone.

Moreover, estuaries are domains of high organic matter (OM) production, cycling, and export to the coastal ocean. They receive numerous contributions of OM from allochthonous (open ocean continent) and autochthonous 


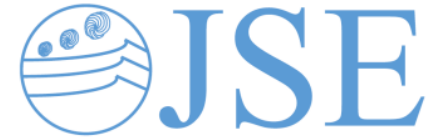

RESEARCH PAPER (derived from the water column itself or from the sediment) sources (Wilson et al., 2005; Lamb et al., 2006; Abrantes and Sheaves, 2008; Botto et al., 2011).

Information regarding the dynamics of $\mathrm{OM}$ sources represents a critical step to explain the carbon concentration/composition, functioning and the energy flows along the estuarine food chain (Meyers, 1994; Botto et al., 2011; Abrantes et al., 2013). Understanding the processes influencing the sources and fate of $\mathrm{OM}$ in estuaries is important for quantifying the contributions of carbon from land and rivers to the global carbon budget of the coastal ocean (Canuel and Hardison, 2016). In this sense, since carbon and nitrogen isotopes $\left(\delta^{13} \mathrm{C}, \delta^{15} \mathrm{~N}\right)$, as well as the total organic carbon/total nitrogen ratio (TOC/TN, hereafter $\mathrm{C} / \mathrm{N}$ ) of different sources have different values, isotopic data are widely used tools to characterize and discriminate different sources of OM preserved in sediments from coastal marine environments (Lamb et al., 2006; Liu et al., 2015; Pérez et al., 2017; Bueno et al., 2018). $\delta^{13} \mathrm{C}$ values are suitable to distinguish between sources of terrestrial C3 plants characterized by relatively low $\delta^{13} \mathrm{C}$ values ( -30 to $24 \%$ ) than C4 salt marsh plants ( -16 to $-12 \%$ ), while marine phytoplankton exhibits intermediate $\delta^{13} \mathrm{C}$ values (-22 to 19\%; Fry and Sherr, 1984; Cloern et al., 2002; Wissel and Fry, 2005; Lamb et al., 2006; Bouillon et al., 2008). C/N values higher than 12 have been related to vascular terrestrial plants rich in cellulose, whereas marine algae tend to be rich in nitrogen thus leading to $\mathrm{C} / \mathrm{N}$ values between 4 and 10 (Meyer, 1994; Wilson et al., 2005). On the other hand, particulate organic matter (POM) from the continent exhibits a lower $\delta^{15} \mathrm{~N}$ signal $(\sim 4.88 \pm 1.45 \%$ ) than that of marine origin $(\sim 6.75 \pm 1.96 \%$ ). These differences have made possible to efficiently use the $\delta^{15} \mathrm{~N}$ values as an OM tracer in aquatic systems (Peters et al., 1978; Sweeney and Kaplan, 1980; Bănaru et al., 2007; Lara et al., 2010; Marchese et al., 2014). Moreover, OM of anthropogenic origin may present a $\delta^{15} \mathrm{~N}$ signature even higher than that provided by marine sources (Sweeney and Kaplan, 1980; Fry et al., 2003). In addition, these variables are used together to reconstruct estuarine scenarios (Lamb et al., 2006).

Dissolved, colloidal and POM is introduced to estuaries by river and groundwater discharge, surface runoff, resuspension events and through the tidal action from the open ocean (Canuel and Zimmerman, 1999; Goñi et al., 2003, 2009; Abrantes et al., 2013). The interaction between such physical forcing and OM is complex and occurs at different temporal and spatial scales (Goñi et al., 2009; Canuel and Hardison, 2016). In addition, human activities developed on basins and coasts (mainly wastewater discharge) imply additional sources of OM to estuaries and introduce further variability to the natural dynamics (Carpenter et al., 1998; de Jonge et al., 2002; Bueno et al., 2018). The relative importance of this OM drivers and their interaction vary among the estuaries, making difficult to identify universal estuarine trends (Canuel and Hardison,
2016). In particular, Río de la Plata estuary (RdlP) as most aquatic systems in South America is strongly affected by the El Niño Southern Oscillation (ENSO) in response to changes of rainfall patterns (Mechoso and Iribarren, 1992, Lüning et al., 2018). During the warm-phase ENSO events, the rainfall pattern increases in southeastern South America thus affecting the hydrological system of the RdIP main tributaries (Paraná and Uruguay rivers) (Depetris et al., 1996; Barreiro, 2010; García-Rodríguez et al., 2014). In addition, it has been shown that precipitation anomalies caused by the El Niño event are higher during the warm (or positive) phase of Pacific Decadal Oscillation (PDO), an ocean-atmosphere variability produced over the Pacific basin (Mantua et al., 1997; Garreaud et al., 2009).

Furthermore, this estuarine system is being subjected to anthropogenic impacts from the runoff of La Plata basin (erosion, soil and fertilizers), and point sources (industrial and urban effluents) as well as from large cities such as Montevideo and Buenos Aires (Nagy et al., 2002; Bonachea et al., 2010; Botto et al., 2011; Venturini et al., 2015).

The aim of this study was to examine the sedimentary organic matter (SOM) sources and to assess the spatial distribution and temporal variability in a large estuarine system, the RdlP estuary. For this purpose, this work integrates recent and historical carbon and nitrogen isotopes $\left(\delta^{13} \mathrm{C}, \delta^{15} \mathrm{~N}\right), \mathrm{C} / \mathrm{N}$ ratios, total organic carbon (TOC), total nitrogen (TN), and sediment grain size analyses along the RdlP estuary. Previous studies on the biochemical composition of sediments within the RdlP (Burone et al., 2013; García-Rodríguez et al., 2014; Venturini et al., 2015; Pérez et al., 2017; Bergamino et al., 2017; Bueno et al., 2018) have been undertaken mainly focusing on the estuarine/marine section or consisted of one single survey. To fill this gap, we investigated temporal and spatial variations using data of three surveys consisting of 25 sediment surface stations located from the freshwater to the marine section of RdlP, plus a sediment core taken from the maximum turbidity zone (MTZ), where the sedimentation processes are dominated by fine sediment fractions.

\subsection{Study area}

The present study was carried out in the RdlP estuary $\left(34^{\circ} 10^{\prime}-6^{\circ} 20^{\prime} \mathrm{S}, 55^{\circ} 00^{\prime}-58^{\circ} 30^{\prime} \mathrm{W}\right)$ (Fig.1). It is the second largest fluvial system in South America and drains a catchment area of $3.1 \times 10^{6} \mathrm{~km}^{2}$ (Acha et al., 2008). The estuary is formed by the confluence of Paraná and Uruguay Rivers which generate together a mean discharge of 23,000 $\mathrm{m}^{3} / \mathrm{s}$, with a more important contribution of Paraná River (Codignotto and Kokot, 2005). It is shallow, i.e., 5-15 m water depth, and the tide range is microtidal, averaging $\sim 0.60 \mathrm{~m}$ with a broad and permanent connection to the sea (Framiñan and Brown, 1996).

The RdlP estuary evolved on a substratum formed during the Holocene. It comprises the "RdIP Geomorphological 
Unit", which is formed by the subaerial delta of Paraná, the coastal plains of the northeast of Buenos Aires and the south of Entre Ríos (emerging geoforms) and the sub-aquatic delta of Paraná (submerged geoform) (Cavallotto, 2002; Cavallotto and Violante, 2005).

The estuary can be divided into three sections according to the sediment composition: the upper reaches (southern limit Colonia - Buenos Aires) where the sediments are dominated by sand, the middle reaches (comprised between the Colonia - Buenos Aires and Montevideo- Punta Piedras) with predominance of silt, and the lower reaches (Montevideo - Punta Piedras and Punta del Este - Punta Rasa) where silt and clay are the most abundant fractions (Framiñan and Brown, 1996; Nagy et al., 2002; FREPLATA, 2004; INA-FREPLATA, 2012; Fossati et al., 2014). Such a gradient distribution of the sediments is associated with the decrease in energy flow of the river currents that are more or less parallel to both coasts of the RdlP (Cavallotto, 2002). In addition, the distribution of sediments in lower reaches is also influenced by marine materials, effect of tides, waves and by the interaction between river and oceanic water masses (FREPLATA, 2004; Cavallotto and Violante, 2005). The maximum turbidity zone (MTZ) is located in the middle reaches and define the transition between estuarine and marine domains (Framiñan and Brown, 1996). This area, with the highest suspended solid concentration, is located near the bottom salinity front following approximately the 10-m isobath (Acha et al., 2008). Turbidity levels in the lower reaches remain low under normal weather conditions, while storms increase resuspension processes thus leading to high turbidity levels (Fossati et al., 2014). The circulation in this part of the estuary is purely micro-tidal (Fossati et al., 2014).
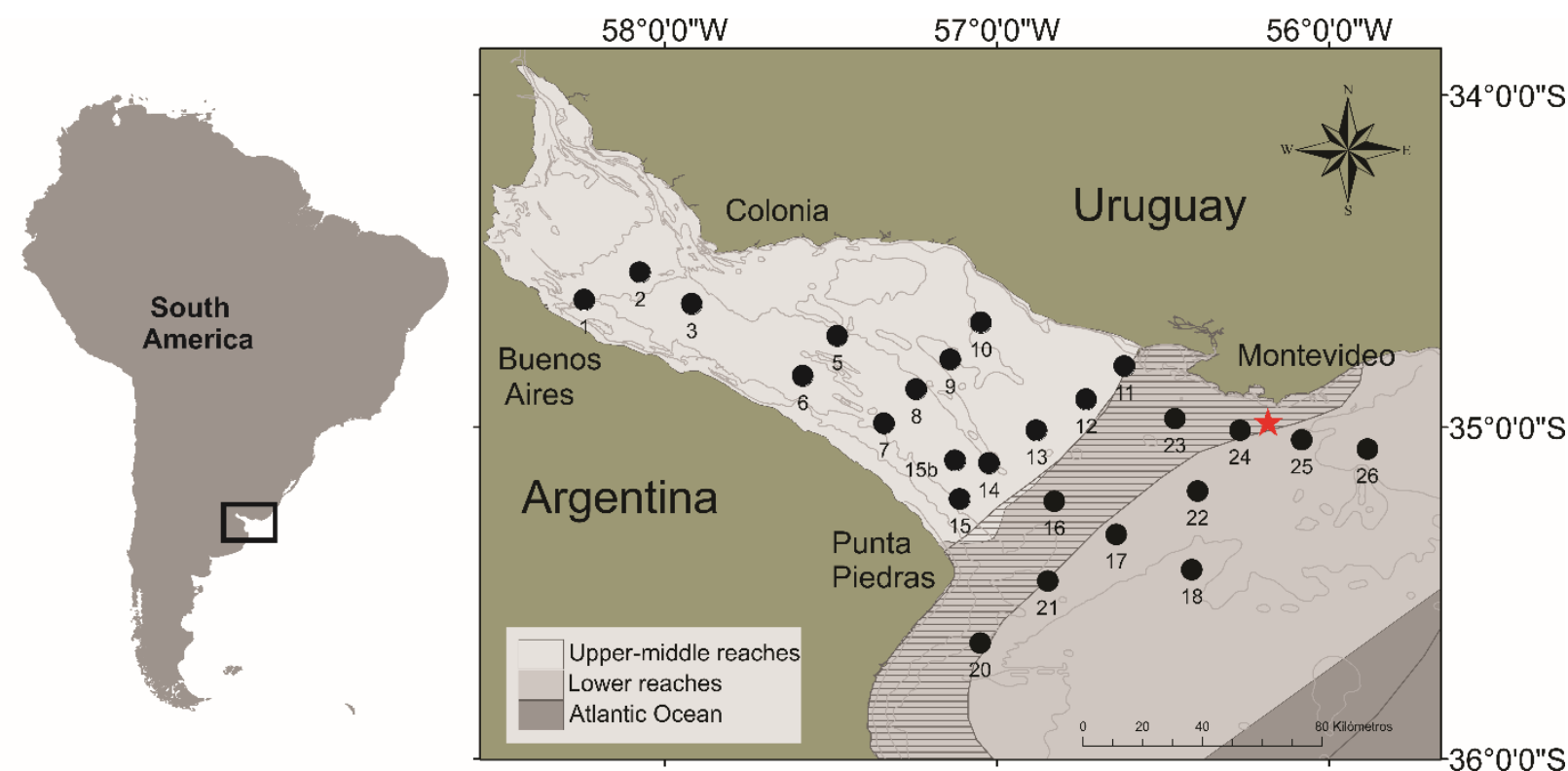

Fig. 1. Map of Rio de la Plata estuary (RdIP) located on the southeastern coast of South America. The sampling sites for surface sediments and salinity measure are indicated with black dots. Red star shows collection site of sediment core (BAR1). Striped area represents maximum turbidity zone (MTZ).

\section{Materials and Methods}

\subsection{Sample collection}

Samples of surface sediments were collected in March, June and December 2010, from 25 stations within the RdlP estuary during one-week cruises (FREPLATA-Ifremer Research). Sampling stations were located in the upper, middle and lower reaches of the estuary (Fig. 1). Sediment samples were collected with a van Veen grab $\left(0.052 \mathrm{~m}^{2}\right)$ and then lyophilized. Bottom water salinity was measured in-situ with a CTD. Additionally, a $25 \mathrm{~cm}$ long core (BAR1) was collected by scuba diving in October 2013 approximately 11 $\mathrm{km}$ off Montevideo coast at a water depth of $10 \mathrm{~m}\left(35^{\circ}\right.$ $\left.03^{\prime} 00^{\prime \prime} \mathrm{S} ; 56^{\circ} 09^{\prime} 00^{\prime \prime} \mathrm{W}\right)$. The sediment core was transported to the laboratory, where it was cut every $1 \mathrm{~cm}$ intervals and then lyophilized.

\subsection{Laboratorial analyses}

Sediment samples were ground to a fine homogeneous powder by using a mortar and pestle for elemental (TC and $\mathrm{TN}$ ) and bulk isotope analyses, including the measurement of $\delta^{13} \mathrm{C}$ and $\delta^{15} \mathrm{~N}$. Samples intended for TC and $\delta^{13} \mathrm{C}$ analyses were treated with $10 \% \mathrm{HCl}$ to remove carbonates, rinsed with distilled water and then dried again for $24 \mathrm{~h}$ at $60^{\circ} \mathrm{C}$. All samples were then analysed using a Thermo Finnigan Flash EA 1112 series elemental analyser equipped with a Thermo Finnigan Delta Plus XP isotope-ratio technology mass spectrometer at the Centro de Aplicaciones de Tecnologia Nuclear en Agricultura Sostenible (Uruguay). Results are expressed as per thousand (\%o) using the $\delta$ notation defined by the equation: $\delta^{13} \mathrm{C}$ or $\left.\delta^{15} \mathrm{~N}(\% 0)=\left[\left(\mathrm{R}_{\text {sample }} / \mathrm{R}_{\text {standard }}\right)-1\right)\right] \times 1000$, where $\mathrm{R}$ is ${ }^{13} \mathrm{C} /{ }^{12} \mathrm{C}$ for carbon and ${ }^{15} \mathrm{~N} /{ }^{14} \mathrm{~N}$ for nitrogen of 
the sample and the standard (Vienna Pee Dee Belemnite for carbon and atmospheric $\mathrm{N}_{2}$ for nitrogen), respectively.

Grain size analyses were undertaken at the Sedimentology laboratory of the Geology Department, Exact and Natural Sciences of the Buenos Aires University. Sediment samples were sieved with a $2 \mathrm{~mm}$ mesh sieve, treated with $20 \% \mathrm{H}_{2} \mathrm{O}_{2}$, and then measured with a CILAS particle size analyser.

\subsection{Data analyses}

Concentration maps of geochemical variables of surface sediments were drawn with the program ArcMap (ArcGis). Data are plotted with circles of different size according the different concentration and rates values. Shape contour maps were obtained from Ecoplata/MVOTMA (https://www.dinama.gub.uy/oan/?page_id=70; Access 1.08.2018).

Statistical analyses were performed with the program PAST 3.10. Since geochemical $\left(\delta^{13} \mathrm{C}, \delta^{15} \mathrm{~N}, \mathrm{TC}\right.$ and TN $)$ and sediment size data did not adjust to a normal distribution, significant differences were assessed using the U-MannWhitney non-parametric test (Sokal and Rohlf, 2012) and 95\% confidence level. Principal Component Analysis (PCA) was performed for all surface sediment variables including $\delta^{15} \mathrm{~N}, \delta^{13} \mathrm{C}, \mathrm{C} / \mathrm{N}$ ratio, grain size fractions and bottom salinity to assess major environmental trends in the study area. All data were first transformed by a Box-Cox and standardized (by subtracting the mean and dividing by the standard deviation) (Hammer et al., 2001).

The geochemical variables of core BAR 1 were analysed by cluster analysis considering TC, TN percentages, $\delta^{15} \mathrm{~N}$, $\delta^{13} \mathrm{C}$ and the sedimentation rate as variables using the Morisita similarity index (Hammer et al., 2001) to identify zones. The zones were collated with historical data of climatic indexes, i.e., PDO and ENSO and average rivers discharge to help explain the zonation. Climatic data were obtained from the Joint Institute for the Study of the Atmosphere and Ocean, University of Washington (http://jisao.washington.edu; Access 5.5.2018). Monthly average discharge values of both Paraná and Uruguay River were obtained from the Integrated Hydrologic Database (http://bdhi.hidricosargentina.gob.ar; Access 5.5.2018) of the Secretary of Water Resources, Argentina. Stations representing the Paraná and the Uruguay River are 'Túnel subfluvial' and 'Paso de los Libres' respectively. Relative anomalies of river discharge were calculated following Piovano et al. (2004) as follows:

$$
\mathrm{Q}=\left(\mathrm{Q}_{\mathrm{i}}-\mathrm{Q}_{\text {average }}\right) / \mathrm{Q}_{\text {average }}
$$

where $Q_{i}$ is the sum of the monthly discharge averages per year, and $Q_{\text {average }}$ is the average of all values of the time series (i.e. 1909-present). Thus, changes in river discharge help visualize deviation from the historical average expressed as positive and negative anomalies.

Correlation analyses were also carried out between the different pair of variables analysed in sediment core and flow anomalies and climate indices. Prior to performing the correlations, the Shapiro-Wilk normality analysis was run. In case of normality, Pearson's linear correlation was applied; otherwise the Spearman correlation was performed. These analyses were also carried out with the free software PAST version 3.

In addition, to examine the proportional contribution, different sources of OM to the surface and core sediments, Bayesian mixing model, i.e., SIAR (Stable Isotope Analysis in R; Parnell et al., 2010) was performed. Such a Bayesian model incorporates uncertainty and variation in parameters such as the fractionation factor. Only sources documented within the RdIP were included in the models (Table 1). C3 and $\mathrm{C} 4$ plants, marine particulate organic matter (MPOM), continental particulate organic matter (CPOM), phytoplankton end-member signatures were obtained from the regional literature (Lara et al., 2010; Botto et al., 2011; Derisio et al., 2014; Marchese et al., 2014). This model was run for each sampling date taking into account the $\delta^{15} \mathrm{~N}$ and the $\delta^{13} \mathrm{C}$ value. We assumed small carbon and nitrogen fractionation factors ( 0.5 for both) based on short-term degradation experiments (Schweizer et al., 1999; Dehairs et al., 2000).

Tab. 1. $\delta^{13} \mathrm{C}$ and $\delta^{15} \mathrm{~N}$ data source values and enrichment factor used for SIAR analysis. Data for RdlP source includes: Marine particulate organic matter (MPOM) from Derisio et al. (2014) and Lara et al. (2010). Continental particulate organic matter (CPOM) from Marchese et al. (2014). Phytoplankton from Derisio et al. (2014) and Marchese et al. (2014). Freshwater marsh plants (C3 mainly) and Saltwater marsh plants (mainly C4) from (Botto et al., 2011).

\begin{tabular}{|c|c|c|c|c|c|}
\hline Variables & MPOM & СРОМ & Phytoplankton & C3 & C4 \\
\hline$\delta^{13} \mathrm{C}$ & $19 \pm 1.0$ & $26 \pm 1$ & $-20 \pm 0.8$ & $-27 \pm 1,1$ & $-13 \pm 2$ \\
\hline$\delta^{15} \mathrm{~N}$ & $8.8 \pm 0.4$ & $6.7 \pm 1$ & $6.3 \pm 1$ & $8 \pm 0.7$ & $4 \pm 4$ \\
\hline \multicolumn{6}{|c|}{ Enrichment Factor (EF) } \\
\hline$\delta^{13} \mathrm{C}$ & $0 \pm 0.5$ & $0 \pm 0.5$ & $0 \pm 0.5$ & $0 \pm 0.5$ & $0 \pm 0.5$ \\
\hline$\delta^{15} \mathrm{~N}$ & $0 \pm 0.5$ & $0 \pm 0.5$ & $0 \pm 0.5$ & $0 \pm 0.5$ & $0 \pm 0.5$ \\
\hline
\end{tabular}




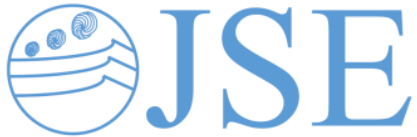

RESEARCH PAPER

\section{Results}

\subsection{Surface sediment}

Figure 2 shows the percentage of the clay, silt and sand fractions of the surface sediment for each sampling station for the different surveys. There is a general trend of grain size decreased from the river mouth (with high sand content) to the MTZ (with high clay content in the stations downstream to MTZ). In some stations, high percentages of gravel-size components were observed associated to the presence of bivalves and gastropods remains. No significant differences in sand content were detected among surveys. For silt and clay, significant differences were found between December and the other two surveys $(p<0.05)$.

The percentage of sand in December varied between 0.0 and $13.3 \%$, in March between 0.0 and $19.7 \%$ and in June between 0.0 and $23.0 \%$. The clay average in December varied between 7.1 and $19.1 \%$, in March ranged between 11.0 and $47.3 \%$, while in June oscillated between 11.0 and 47.5. On the other hand, silt ranged between 80.9 and $91.0 \%$ in December, and between 40.8 and 86.0 in March, and finally in June showed values between 35.6 and $86.2 \%$.
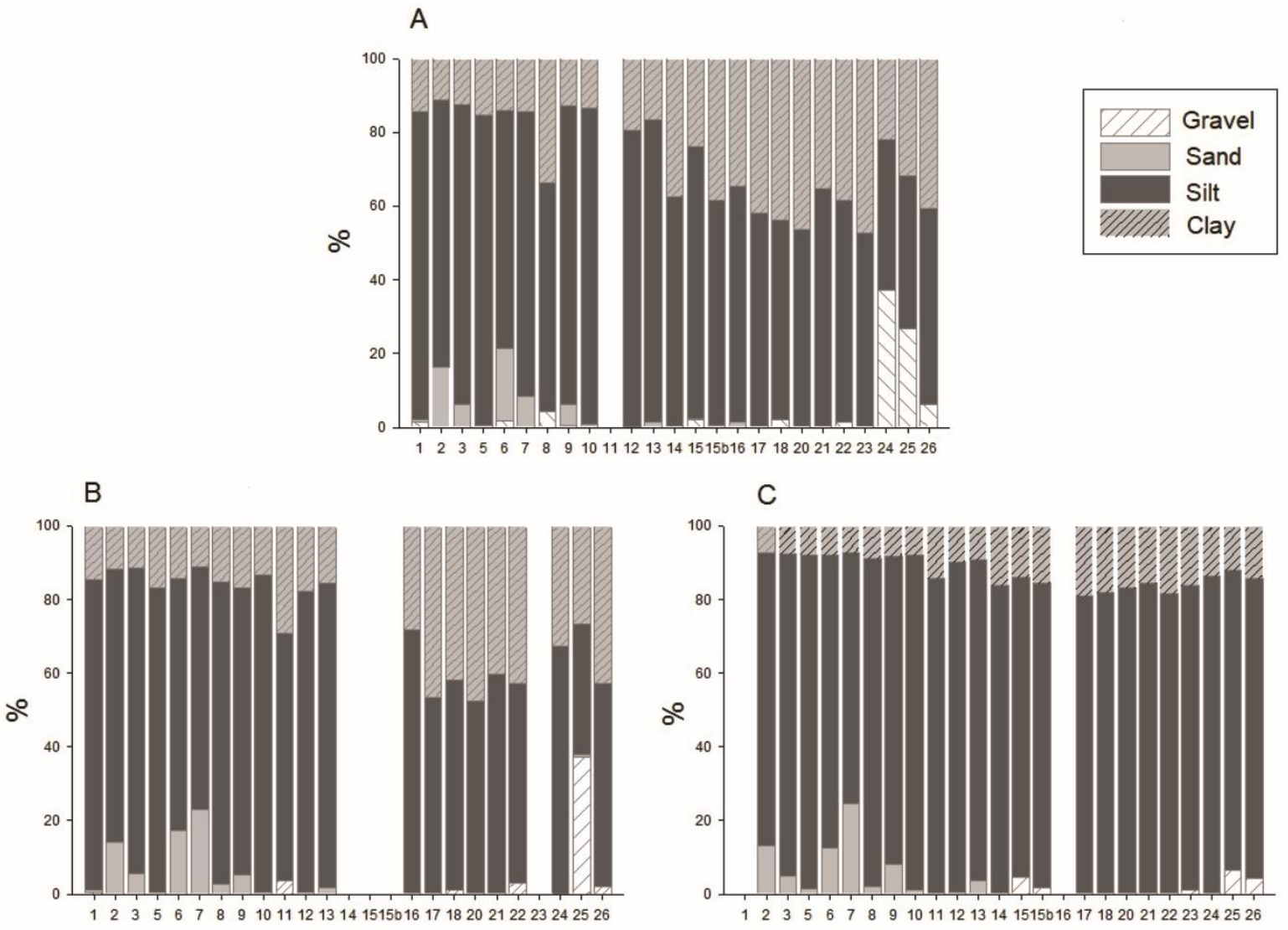

Stations

Fig. 2. Grain size analysis results of surface sediments for the different surveys. The stations are located on the horizontal axis and the percentage of each grain size on the vertical axis. A = March. $\mathrm{B}=$ June. $\mathrm{C}=$ December.

The percentage of TOC in surface sediments ranged between $0.31-1.20 \%$ and $\mathrm{TN}$ varied between $0.03-0.16 \%$. They exhibited a similar trend in all surveys, which consisted of increased values close to the MTZ and maximum values to the east of the MTZ (Fig. 3). C/N ratios, ranged between $6.52-10.44 \%$ and showed the highest values in the upper/middle reaches and close to Montevideo (i.e., stations 24, 25 and 26; Fig. 3). All the variables mentioned above, showed significant differences between December and the other two surveys $(p<0.05)$. Mean TOC in December was $0.76 \pm 0.23 \%, 0.60 \pm 0.17 \%$ in March and $0.57 \pm 0.19 \%$ in June. On the other hand, mean TN value was $0.09 \pm$ $0.03 \%$ in December, $0.078 \pm 0.024 \%$ in June and
$0.07 \pm 0.03 \%$ in March. The highest $\mathrm{C} / \mathrm{N}$ ratio was observed in December (mean value $8.50 \pm 0.74$ ), while similar values were recorded in March (mean values $7.79 \pm 0.70$ ) and June (mean values $7.9 \pm$ $0.71)$.

The $\delta^{13} \mathrm{C}$ and $\delta^{15} \mathrm{~N}$ values did not show significant differences between surveys: $\delta^{13} \mathrm{C}$ ranging between $-26 \%$ and $-20 \%$ and $\delta^{15} \mathrm{~N}$ ranging between $5 \%$ and $10 \%$. The $\delta^{13} \mathrm{C}$ values showed an average of $-24.00 \pm 0.98 \%$ in the upper and middle reaches and $-21.00 \pm 0.50 \%$ in the lower reaches. The $\delta^{15} \mathrm{~N}$ values showed an average of $5.60 \pm 0.50$ in upper and middle reaches and $6.60 \pm 0.80$ in lower reaches. 
TOC $\%$

a)

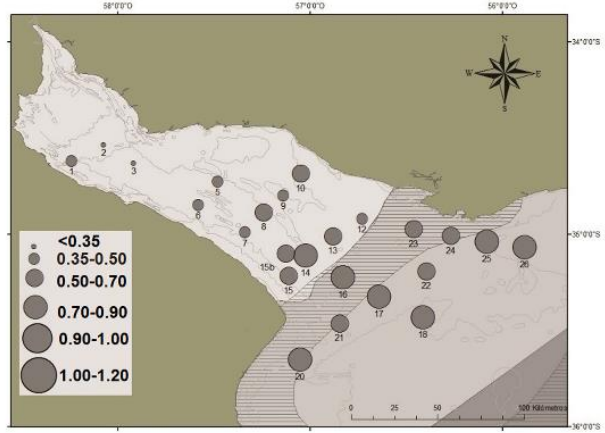

b)

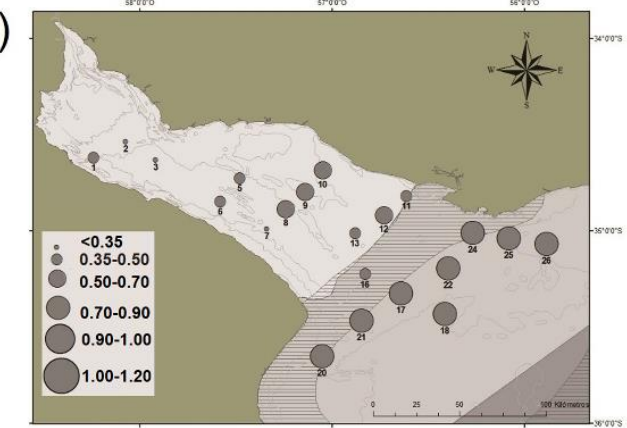

c)

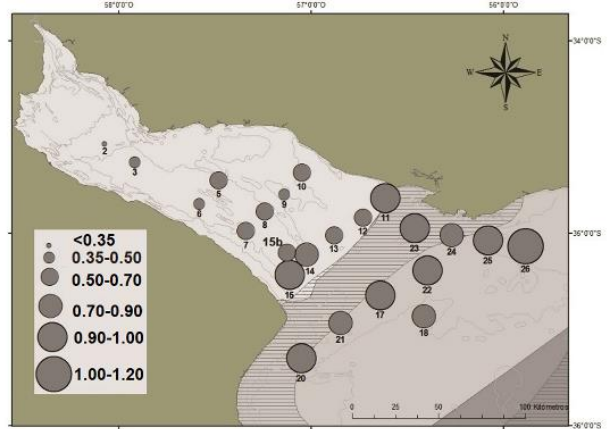

TN \%
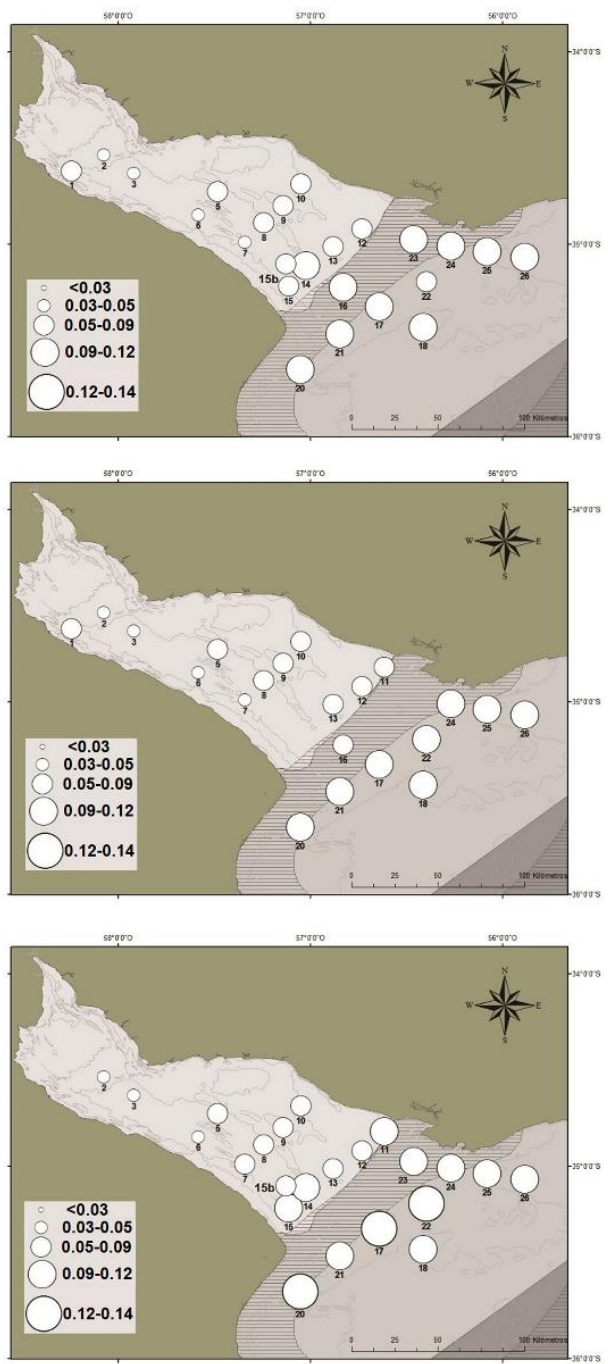
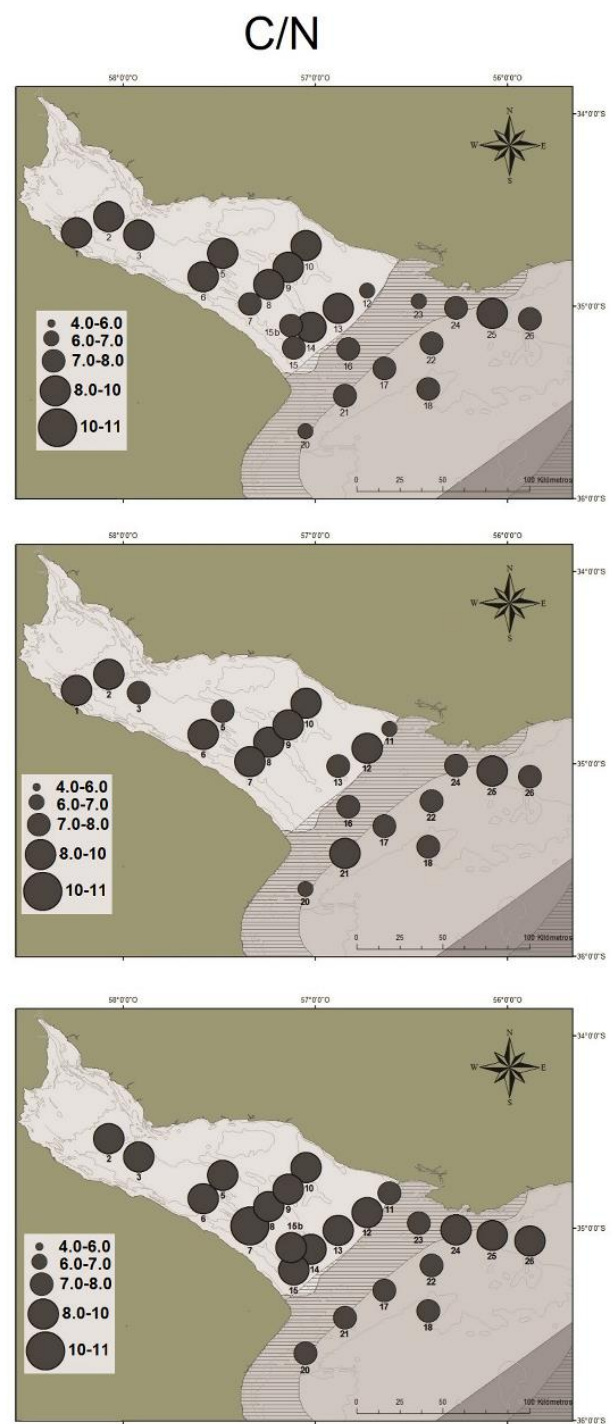

Fig. 3. Maps of TOC, TN percentage and C/N ratio on SOM from: a) May; b) June and; c) December surveys. 


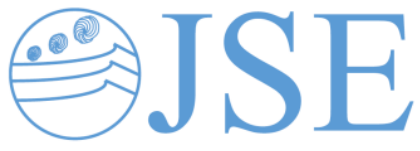

RESEARCH PAPER
Figure 4a shows the PCA diagram for surface sediment geochemical variables, bottom salinity and grain size. The first principal component (PC 1) accounted for 63\% and the second axis (PC 2) accounted for $15 \%$ of the variance. The high scores on the first axis were mainly explained by a positive association with $\delta^{13} \mathrm{C}$ and TN. The second axis was mainly explained by the silt content and was negatively associated to the clay content. The distribution pattern of samples resembles the location of the stations, i.e., the lower reaches to the right side of the plot, while the upper and middle reaches (hereafter upper reaches) are located to the left side (Fig. 4b).
Table 2 shows the correlation between geochemical variables and salinity. All geochemical variables showed significant and positive correlation with salinity and clay, except for the $\mathrm{C} / \mathrm{N}$ ratio that exhibited significant and negative correlation with aforementioned variables. On the other hand, both sand and silt content correlated positively only with the $\mathrm{C} / \mathrm{N}$ ratio.

The SIAR outputs indicated that in the upper and lower estuary, continental particulate organic matter (CPOC) was the main $\mathrm{OM}$ source contributing to $\mathrm{SOM}$, and to less extent, C3 plants in the upper reaches and phytoplankton in the lower reaches (Fig. 5).

Tab. 2. Linear correlations between surface sediment variables: TOC $(\%), \mathrm{TN}(\%), \delta^{13} \mathrm{C}(\% 0), \delta^{15} \mathrm{~N}(\%), \mathrm{C} / \mathrm{N}$ ratio, grain size and salinity. All correlations were statistically significant: in bold for $p<0.01$ and; the others for $p<0.05$.

\begin{tabular}{|c|c|c|c|c|c|c|c|c|c|}
\hline Variables & $\delta^{15} \mathbf{N}$ & $\delta^{13} \mathrm{C}$ & TN & TOC & $\mathrm{C} / \mathrm{N}$ & Sand & Silt & Clay & Salinity \\
\hline$\delta^{15} \mathrm{~N}$ & 1.00 & 0.56 & 0.59 & 0.51 & -0.54 & -0.52 & -0.37 & 0.43 & 0.58 \\
\hline$\delta^{13} \mathrm{C}$ & 0.56 & 1.00 & 0.73 & 0.63 & -0.63 & -0.80 & -0.52 & 0.75 & 0.61 \\
\hline$T N$ & 0.59 & 0.73 & 1.00 & 0.97 & -0.48 & -0.84 & -0.25 & 0.60 & 0.73 \\
\hline TOC & 0.51 & 0.63 & 0.97 & 1.00 & -0.27 & -0.76 & -0.16 & 0.45 & 0.71 \\
\hline$C / N$ & -0.54 & -0.63 & -0.48 & -0.27 & 1.00 & 0.60 & 0.53 & -0.76 & -0.43 \\
\hline Sand & -0.52 & -0.80 & -0.84 & -0.76 & 0.60 & 1.00 & 0.29 & -0.69 & -0.62 \\
\hline Silt & -0.37 & -0.52 & -0.25 & -0.16 & 0.53 & 0.29 & 1.00 & -0.72 & -0.44 \\
\hline Clay & 0.43 & 0.75 & 0.60 & 0.45 & -0.76 & -0.69 & -0.72 & 1.00 & 0.50 \\
\hline Salinity & 0.58 & 0.61 & 0.73 & 0.71 & -0.43 & -0.62 & -0.44 & 0.50 & 1.00 \\
\hline
\end{tabular}

\subsection{Lithology and geochemical analysis of sediment core}

The sediment core was lithologically homogeneous, being characterized by only slight changes in texture type of silt but also small changes in colour. BAR1 showed a distinctive light brown colour with greyish bands in some areas. Changes in grain size and sedimentation rate were published elsewhere (Marrero et al., 2014). Geochronology was calculated from the sedimentation rate.

TC ranged from $1.0 \%$ (on top) to $1.3 \%$, (at $24 \mathrm{~cm}$ ), with most values throughout the sediment core close to 1.2. TN content ranged from $0.09 \%$ (on top) to $0.12 \%(19 \mathrm{~cm}$ ) but most values were close to 0.1 . The $\mathrm{C} / \mathrm{N}$ ratios varied from $10.6(18 \mathrm{~cm})$ to $12(7 \mathrm{~cm})$, being most ratios close to 10.5 . The $\delta^{13} \mathrm{C}$ values showed a decreasing trend from the bottom to the middle section of the core, and then a decreasing trend towards the surface. The $\delta^{13} \mathrm{C}$ values ranged from a minimum value of $-23.25 \%$ (at surface) to a maximum of $21.2 \%$ o $(15 \mathrm{~cm})$. The $\delta^{15} \mathrm{~N}$ values varied from $6.1 \%$ ( $(7 \mathrm{~cm})$ to $7.2 \% 0(9 \mathrm{~cm})$ (Fig. 6$)$.
The cluster analysis based on TC, TN, $\delta^{13} \mathrm{C}, \delta{ }^{15} \mathrm{~N}$ and $\mathrm{C} / \mathrm{N}$ ratios allowed the identification of three main zones (at $83 \%$ similarity level). Zone I grouped 1991-2013 AD, zone II encompassed 1968-1986 AD, while group III included all intervals prior to1968 AD (Fig. 6).

Figure 6 shows the anomalies of both Uruguay and Paraná River, together with the anomalies of the PDO and the Southern Oscillation Index (SOI). PDO showed mainly negative anomalies between 1945 and 1973, but the remaining anomalies were mainly positive for the rest of the study period. The SOI showed cycles of negative and positive interannual oscillations, which were 2 to $7 \mathrm{yrs}$ long, for both positive and negative anomalies. The Paraná and Uruguay River also showed interannual cyclicity of positive and negative anomalies.

Table 3 shows the correlation between climatic indices (i.e., 1900-2013), river anomalies (also for 1909-2013), sedimentation rate and geochemical variables (for 19502013). The PDO correlated positively with SOI and the Paraná River anomalies, while SOI correlated positively to 
both Paraná and Uruguay River anomalies. Uruguay and Paraná rivers' anomalies showed positive correlations, and the Paraná River anomaly was positively correlated to TN.
The sedimentation rate was positively correlated to $\mathrm{C} / \mathrm{N}$ and the PDO climatic index. Finally, TOC and TN showed a high correlation.

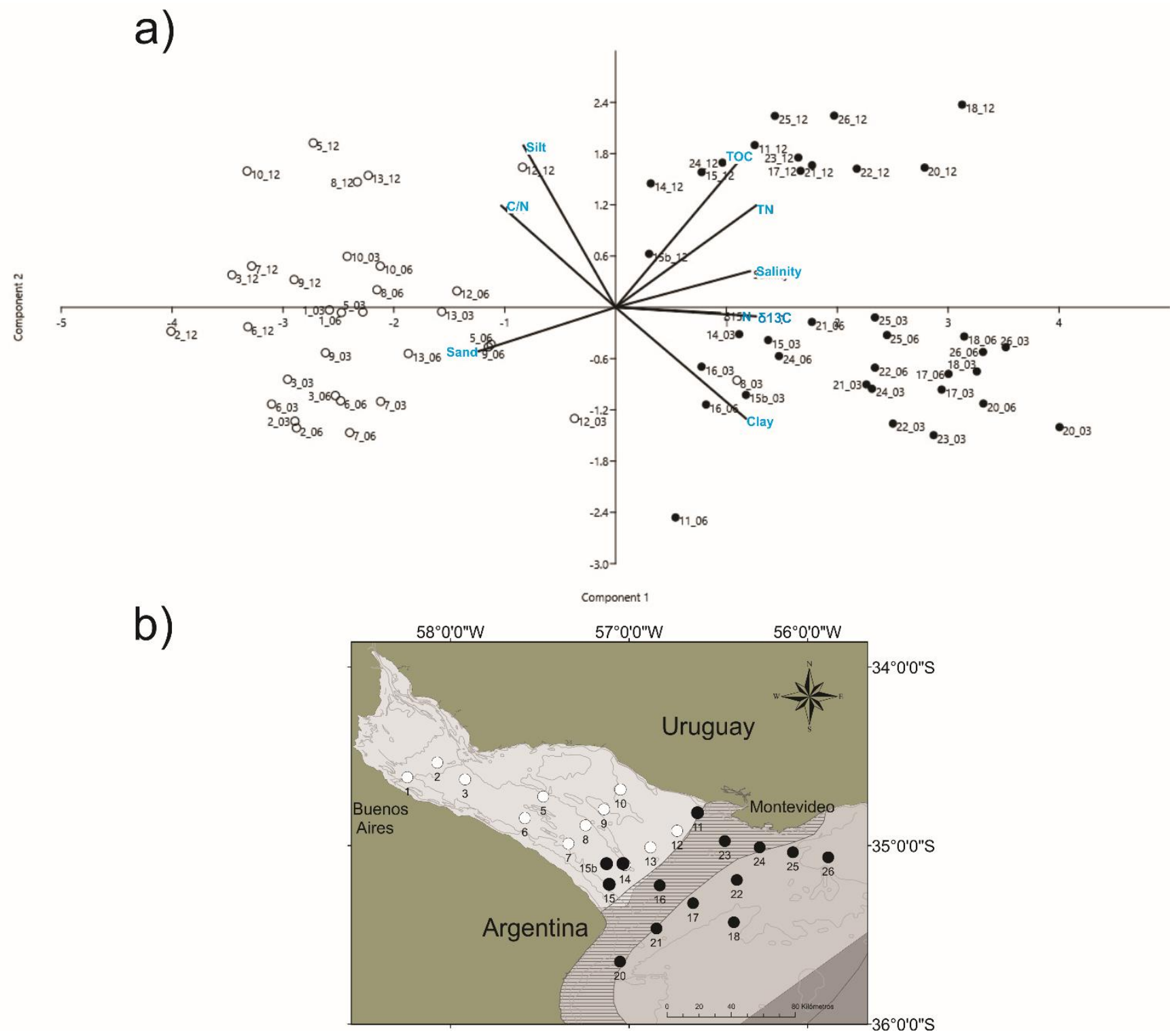

Fig. 4. a) PCA diagram for salinity and surface sediment variables (code: station_survey (month)). Two main groups were obtained (black and white dots). b) Obtained groups are shown in RdlP map with the same dot color as the PCA analysis.

\section{Discussion}

\subsection{Geochemical characteristics of surface sediments}

The PCA analysis suggests the presence of two different pools of SOM, each of them corresponding to the east of the MTZ (lower reaches, black dots) influenced by marine water, and to the west of the MTZ influenced by the river flow (upper reaches, white dots) (Fig. 4). Thus, the lower reach stations are positively associated with clay, salinity, TOC, TN, $\delta^{15} \mathrm{~N}$ and $\delta^{13} \mathrm{C}$ but negatively with $\mathrm{C} / \mathrm{N}$ and sand, while upper reach stations display the opposite trend.
Therefore, there is a clear spatial differentiation in the geochemical composition of the sediments within the RdlP modulated by MTZ (e.g. Botto et al., 2011; Burone et al., 2013; Venturini et al., 2015).

The predominance of clay towards the middle and lower reaches is associated with the flocculation promoted by the mixture of both fresh and marine water, thus generating processes of fine sediment trapping within the MTZ (Simionato et al., 2011; Fossati et al., 2014). In this sense, the MTZ represents in fact a physical barrier that captures fine sediments (Bianchi, 2007). The fine grain size has a large surface area and a higher adsorption capacity of carbon and 


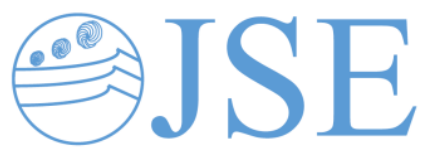

RESEARCH PAPER nitrogen elements (de Falco et al., 2004; Gao et al., 2008). This fact explains the increasing values of TOC and TN to the east of the MTZ (Fig. 3). In addition, TOC and TN exhibited a similar trend and showed high positive correlation $(0.97 ; p<0.05)$, thus suggesting that the sedimentary nitrogen is mainly from organic origin. In this sense, the highest percentage of TOC and TN to the east of

a)

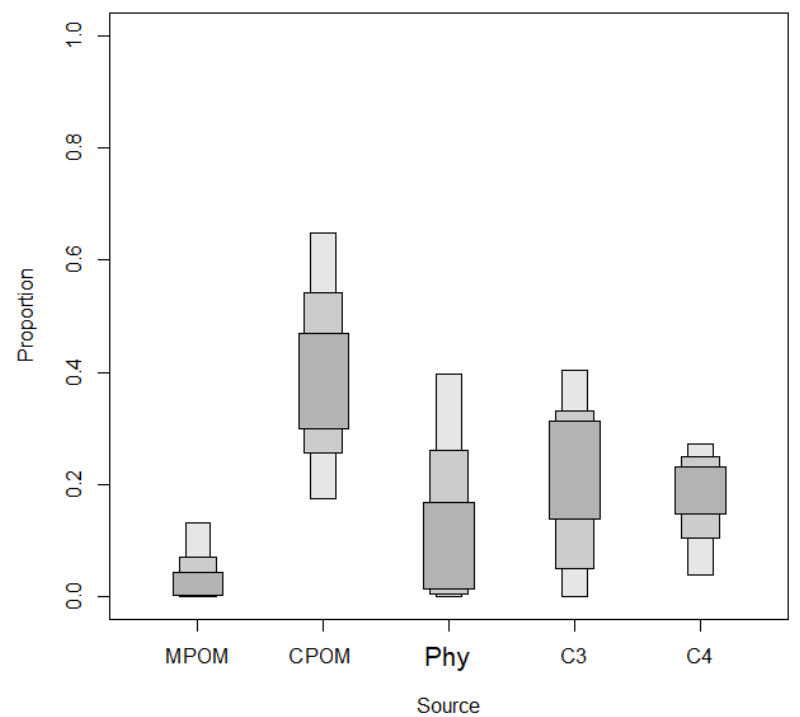

the MTZ is also related to high productivity levels close to the MTZ. An increasing trend in primary productivity towards the external zone of the RdlP has been documented due to the combined effect of nutrient availability (mainly nitrogen) and the reduction in turbidity that results in the predominance of feed deposits (Giberto et al., 2004; Calliari et al., 2005; Acha et al., 2008).

b)

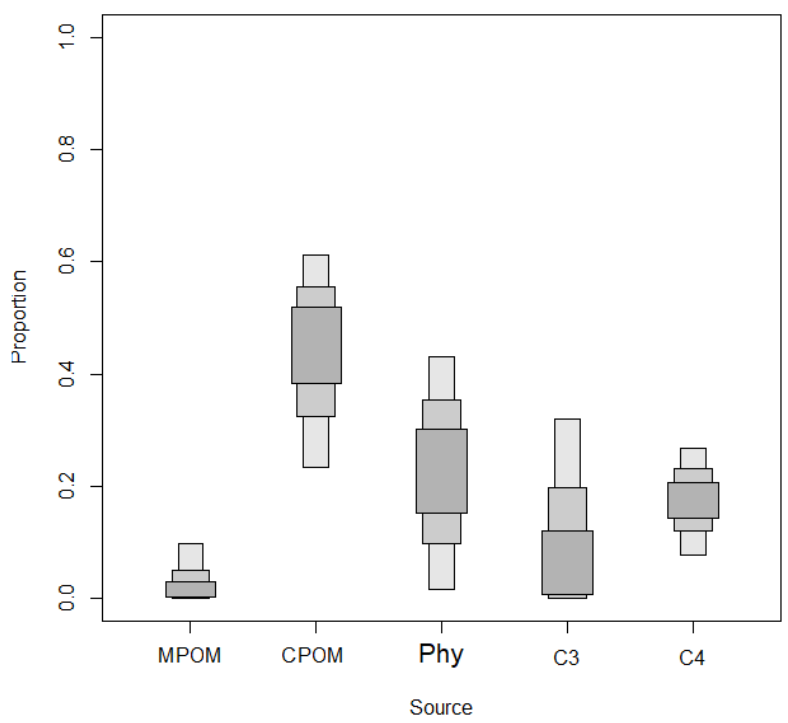

Fig. 5. Results of SIAR mixing models analysis to estimate source contribution to the SOM in RdlP upper (a) and lower (b) reaches. Data from RdlP include: MPOM (Marine particulate organic matter), CPOM (Continental particulate organic matter), Phy (Phytoplankton), C3 (C3 plants from freshwater marsh) and C4 (C4 plants from saltwater marsh).

Stations $14,15 \mathrm{~b}$ and 15 are located to the west of the MTZ on the Argentinean margin, however they were positively associated with the axis 1 of the PCA grouped together with the stations of the lower reaches of the estuary. Its position in the PCA diagram is related to the dominant sediment type, which contains more clay than the stations of the upper reaches. Likewise, the percentages of TC, TN and $\delta^{13} \mathrm{C}$ were higher $(-22 \pm 0.40 \%)$ than in the rest of the stations of the upper reaches (Fig. 3). Such a trend could be explained by the particular dynamics of the area near Punta Piedras and Bahía Samborombón, where the sediments are resuspended by tide effects, but the area is further filled with sediments when large storms occur (Piedra-Cueva and Fossati, 2007; Simionato et al., 2011). Similarly, station 11 (located to the west of the MTZ and closed to Montevideo coastal zone) is positively associated with axis 1 of the PCA together with the external stations. Station 11 also exhibited higher percentages of clay than the neighbouring stations and higher concentration of TC and TN. The MTZ displays a more intense oscillation movement on the Uruguayan coast, so the effect generated by the MTZ and the influence of seawater is higher in 11 stations than in the rest of the upper reach stations (Framiñan and Brown, 1996).

Salinity correlated positively with both $\delta^{15} \mathrm{~N}$ and $\delta^{13} \mathrm{C}$ in close agreement with natural origin of the OM. Terrestrial
OM transported by river represents an important allochthonous source for coastal estuarine sediments (Abrantes et al., 2013) and its inherent organic carbon signature depends on the dominant surrounding vegetation type (i.e., C3 vs. C4). This fact may explain the decreasing $\delta^{13} \mathrm{C}$ trend in surface sediments towards the upper reaches, thus indicating the strong river water influence and $\mathrm{C} 3$ plant material, which exhibits low $\delta^{13} \mathrm{C}$ signatures, i.e., ranging from -24 to $-30 \%$ (Fry and Sherr, 1984; Cloern et al., 2002; Wissel and Fry, 2005). The higher $\delta^{13} \mathrm{C}$ values observed in sediments from the lower reaches were more closely related to marine sources that usually showed $\delta^{13} \mathrm{C}$ values ranging from $-22 \%$ o to $-19 \%$ (Meyer, 1994; Cloern et al., 2002; Lamb et al., 2006), and $\delta^{15} \mathrm{~N}$ for marine phytoplankton typically ranges from $4 \%$ to $10 \%$ consistently with our data (Dean et al., 1986). Other estuaries presented similar patterns of $\delta^{13} \mathrm{C}$ values in sediment with marine dominated regions ranging between $-20 \%$ to $-22 \%$ and river dominated regions ranging between - 23\% to $-26 \%$ respectably (Yu et al., 2010; Liu et al., 2015). These results suggested that organic matter derived from the adjacent ocean had some influence in the distribution of the sedimentary organic matter within the lower reaches of the RdlP.

Moreover, the TC/TN ratio is negatively correlated with salinity and it was associated with stations located to the west 
of MTZ in the PCA diagram. This result can be explained by the higher influence of OM from terrestrial plants on upper reach zone due to the close continental influence, since the plants have a low protein content compared to algae (Meyers, 1994, 2003; Pittau et al., 2001; INA-FREPLATA, 2012).

On the other hand, SIAR analysis shows CPOM as a main source of SOM in RdIP upper and lower reaches, but
RESEARCH PAPER

also shows a higher contribution of C3 plants in upper reaches than in lower reaches, while phytoplankton contribution increased towards the lower reaches. This agrees with Burone et al. (2013) and Bergamino et al. (2017) those inferred that the upper reach sediments receive OM mostly from allochthonous sources (freshwater sources and C3 plant detritus) and autochthonous OM was shown to increase towards the lower reaches (marine algae).

Tab. 3. Linear correlations between the Uruguay and Paraná Rivers anomalies, the SOI and PDO climatic indices, the sedimentation rate and the different variables analyzed in the BAR 1 . In the case of the Paraná River the result is the Spearman correlation. The coefficients shown in bold indicate $p<0.05$ and with $* p<0.01$.

\begin{tabular}{|c|c|c|c|c|c|c|c|c|c|c|}
\hline Variables & $\mathrm{V}\left(\mathrm{cm} \mathrm{y}^{-1}\right)$ & TOC & $\mathbf{T N}$ & $\mathrm{C} / \mathrm{N}$ & $\delta^{15} \mathbf{N}$ & $\delta^{13} \mathrm{C}$ & Paraná & Uruguay & PDO & SOI \\
\hline$V\left(c m y^{-1}\right)$ & 1 & 0.48 & -0.12 & 0.5 & -0.08 & 0.16 & 0.22 & 0.21 & 0.53 & -0.30 \\
\hline TOC & 0.48 & 1.00 & $* 0.82$ & 0.39 & 0.32 & 0.13 & -0.4 & -0.20 & 0.01 & -0.10 \\
\hline$T N$ & -0.12 & $* 0.82$ & 1.00 & -0.21 & -0.22 & 0.25 & -0.55 & -0.38 & -0.25 & 0.17 \\
\hline$C / N$ & 0.5 & 0.39 & -0.21 & 1 & -0.19 & 0.21 & 0.27 & 0.28 & 0.31 & 0.46 \\
\hline$\delta^{15} \mathrm{~N}$ & -0.08 & -0.32 & -0.22 & -0.19 & 1.00 & 0.57 & -0.21 & 0.14 & -0.16 & 0.41 \\
\hline$\delta^{13} C$ & 0.16 & -0.13 & -0.25 & 0.21 & 0.57 & 1.00 & 0.12 & -0.02 & 0.20 & 0.05 \\
\hline Paraná & 0.22 & -0.40 & -0.55 & 0.27 & -0.21 & 0.12 & 1.00 & 0.68 & 0.48 & 0.38 \\
\hline Uruguay & 0.21 & -0.20 & -0.38 & 0.28 & 0.14 & 0.02 & 0.68 & 1.00 & 0.26 & 0.35 \\
\hline PDO & 0.53 & 0.01 & -0.25 & 0.31 & -0.16 & 0.20 & 0.48 & 0.26 & 1.00 & $* 0.74$ \\
\hline SOI & -0.3 & -0.10 & 0.17 & -0.46 & 0.41 & 0.05 & -0.38 & -0.35 & *-0.74 & 1.00 \\
\hline
\end{tabular}

The second axis of the PCA grouped the stations of December's survey far apart from the other two. In his sense, the component 2 is mainly explained by silt. Furthermore, significant differences were observed for TOC, TN and C/N $(p<0.05)$ between December and the other surveys. This observed difference could be associated to the warm phase of the ENSO event registered prior to December 2010. This event led to significant increases in the flow of the estuary which caused an evident change in the geochemistry of the Río de la Plata sediments (i.e., increasing sediment content of protein, organic matter, chlorophyll-a and phaeopigment) (García-Rodríguez et al., 2014).

\subsection{Historical aspects of $\mathrm{R} d I \mathrm{P}$ sediment $\mathrm{OM}$}

Compared to other costal zones, estuaries and the Uruguayan continental shelf (de Souza et al., 2012; Martins et al., 2012; Sánchez-Cabeza et al., 2012; de Mahiques et al., 2013; Pérez et al., 2016, 2017), the sedimentation rate of core BAR1 (see Marrero et al., 2014) displays medium/low values $\left(0.08 \mathrm{~cm} \mathrm{yr}^{-1}-0.52 \mathrm{~cm} \mathrm{yr}^{-1}\right)$. This can be explained by the high dynamics of flocculation, convection, erosion, resuspension and transport processes observed in the study area (FREPLATA, 2004; Framiñan et al., 2008; Fossati et al., 2014). Moreover, Bonachea et al. (2010) observed higher sedimentation rate (from $0.3 \mathrm{~cm} \mathrm{yr}^{-1}$ to $1.2 \mathrm{~cm} \mathrm{yr}^{-1}$ ) in Samborombón Bay by using the same methodology as
Marrero et al. (2014). Therefore, the MTZ appears to modulate sediment deposition processes, where higher sedimentation rate takes place on the Argentinean coast, i.e., in Samborombón Bay (Framiñan et al., 1999; Fossati et al., 2014).

In the 1970s, a PDO polarity change was observed (from cold to warm), that also further observed in the 1980s and 1990s. ENSO events became more frequent and intense compared to the previous three decades. As a consequence of the increase in rainfall over Southeast South America, a positive trend in the RdlP flow was recorded (Barros et al., 2000; Camilloni, 2005; Mauas et al., 2008; Garreaud et al., 2009). In addition, during the last 30 years of the $20^{\text {th }}$ Century, the Paraná River flow was 20\% higher than the mean historical values (Mauas et al., 2008).

In this sense, Table 3 shows that the SOI is negatively/significantly correlated to the anomalies of both Paraná and Uruguay River, while the PDO is positively/significantly related to the Paraná River anomaly Hence, at least for the timeframe considered in this paper, a positive relationship between the increase in river flow and climatic indices was inferred.

The core zones obtained from the cluster analysis (Fig. 6) are in agreement with the above mentioned climatic and hydrological variations. Thus, the cluster group corresponding to prior to 1968 , contains data with a differential behaviour to that of the most recent two groups (i.e., 1968-1986, 1991-2013). 


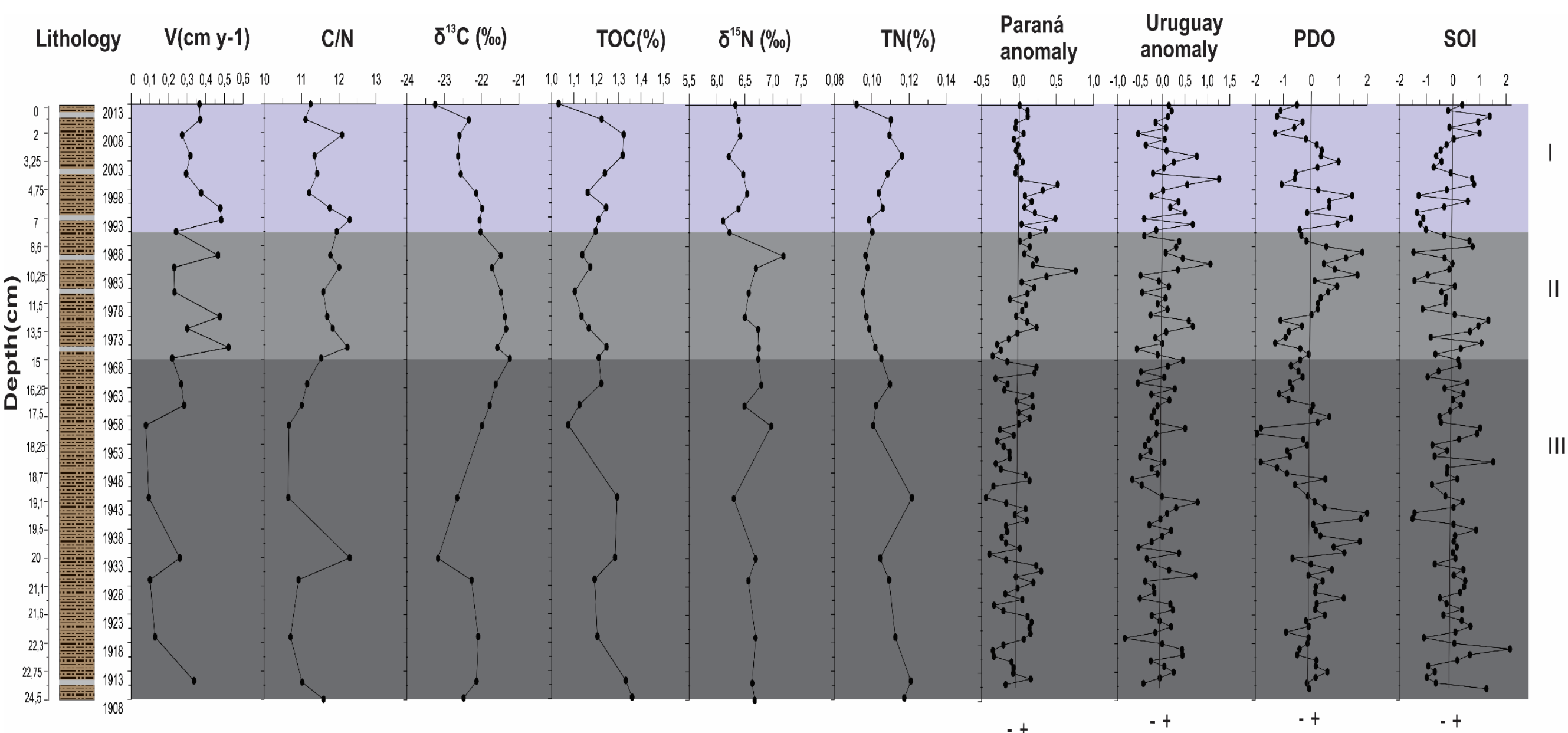

Fig. 6. Variations experienced in the last 100 years of: SOI and PDO climatic indices, Q anomalies of the Paraná and Uruguay River, and sediment variables TN, $\delta^{15} \mathrm{~N}, \mathrm{TOC}, \delta^{13} \mathrm{C}, \mathrm{C} / \mathrm{N}$ ratio and sedimentation rate (V) (presented from left to right). The grey colors show the groups formed from cluster analysis. Geochronology was calculated from the sedimentation rate (Marrero et al., 2014). 


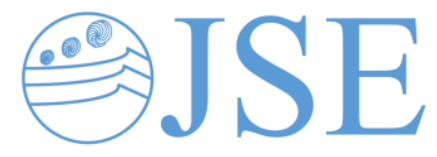

RESEARCH PAPER

The sedimentation rate was higher and more variable in the most recent zones, probably associated to the increasing trends registered in both Paraná and Uruguay River flow during the last decades (Mauas et al., 2008; Marrero et al., 2014).

Moreover, there is a clear shift in $\delta^{13} \mathrm{C}$ to a decreasing trend since $1970(-21.30 \%$ ) to $2013(-23.25 \%$ ) that reveals an increase in river influence. Consistently, there is an increasing trend in C/N ratios between 1970 and 1993 (average $11.90 \pm 0.25$ ) that correlated positively with the sedimentation rate (Table 3), probably due to an increased continental influence (Meyers, 2003). Also, sedimentation rate correlated positively with the PDO index (Table 3). Likewise, the flow anomaly of the Parana River correlated positively with the PDO and negatively with the TN. Thus, the increase in Paraná River flow as a PDO consequence, explains the increase in sediment accumulation rate and the changes of OM characteristics in BAR1.

The location of the MTZ is an important factor influencing the productivity in the lower estuary and displays variability in association with different climatic and hydrological forcing factors (Framiñan and Brown, 1996; Acha et al., 2008; Simionato et al., 2011). Therefore, the MTZ shift towards the lower reaches of the estuary as a consequence of long-term hydrological changes, explains the decrease in the influence of marine phytoplankton on the SOM from lower reaches sites (Framiñan and Brown, 1996; Acha et al., 2008; Simionato et al., 2011). Given that El Niño and la Niña are events of decadal variability, the lack of correlations between SOI and the geochemical variables presented in this study, may be due to the resolution of core BAR1 which is not good enough to infer interannual processes linked to ENSO.

Generally, $\delta^{15} \mathrm{~N}$ values along the estuarine gradients reflect the influence of human activity and wastewater inputs from catchments that are isotopically rich in heavy $\delta^{15} \mathrm{~N}$ (Sweeney and Kaplan, 1980; Kuramoto and Minagawa, 2001; Fry et al., 2003; Savage, 2005; Serna et al., 2010). Since 1980 , toxic algal blooms have been documented in RdlP as a symptom of eutrophication (Méndez and Ferrari, 2002; Nagy et al., 2002).

Nevertheless, in this work, TOC and TN from both surface and core sediments showed high correlations $(0.97$ and $0.82, p<0.01)$, meaning that TN appears to be mainly organic nitrogen. In addition, the relatively low $\delta^{15} \mathrm{~N}$ values found in the sediments from the core BAR1 and in surface sediments indicate that dilution of potential anthropogenic inputs from domestic effluent may prevent environmental impacts. This fact together with the nutrient removal effect inherent to oceanographic processes may explain the absence of a clear eutrophication trend in the sedimentary record (Nagy et al., 2002).

\section{Conclusion}

This work evidences that the MTZ in a large estuary represents a physical barrier between contrasting zones with different geochemical composition. It was possible to spatially discriminate such geochemically contrasting zones and suggested that the SOM was influenced by the dynamics of the surface layer of the estuary. Moreover, we observed that CPOM is the main OM source of the RdlP sediments but there is also a significant contribution of living phytoplankton in the lower estuary and OM from plant litter in the upper estuary.

On the other hand, our findings suggested that an increase in the flow of the Paraná River, which is related to the change of polarity of the PDO from 1970, exerted a major influence on the SOM composition, leading to an increased input of terrigenous material. Therefore, multidecadal climatic variations might ultimately influence the contributions of carbon from land and rivers to RdIP.

\section{Acknowledgment}

This project was funded by Intendencia de Montevideo (IM), and Proyecto - Programa de Monitoreo del Río de la Plata y su Frente Maritimo (FREPLATA) /Institute Français de Recherche pour l'Exploitation de la Mer (IFREMER). PEDECIBA-Geociencias, AUGM (Mobility Program for Postgraduate Students) and ANII (SNI and postgraduate fellowships), are also thanked for the financial support. The authors would like to express sincere thanks to our colleagues at the Oceanography and Marine Ecology Laboratory of Facultad de Ciencias, Universidad de la República.

\section{References}

Abrantes, K., Barnett, A., Marwick, T., Bouillon, S., 2013. Importance of terrestrial subsidies for estuarine food webs in contrasting East African catchments. Ecosphere 4(1), 1-33. https://doi.org/10.1890/ES12-00322.1

Abrantes, K., Sheaves, M. 2008. Incorporation of terrestrial wetland material into aquatic food webs in a tropical estuarine wetland. Estuarine, Coastal and Shelf Science 80(3), 401-412. https://doi.org/10.1016/j.ecss.2008.09.009

Acha, E., Mianzan, H., Guerrero, R., Carreto, J., Giberto, D., Montoya, N., Carignan, M., 2008. An overview of physical and ecological processes in the Rio de la Plata Estuary. Continental Shelf Research 28, 1579-1588. https://doi.org/10.1016/ j.csr.2007.01.031

Bănaru, D., Harmelin-Vivien, M., Gomoiu, M., Onciu T., 2007. Influence of the Danube River inputs on $\mathrm{C}$ and $\mathrm{N}$ stable isotope ratios of the Romanian coastal waters and sediment (Black Sea). Marine Pollution Bulletin 54(9), 1385-1394. https://doi.org/10.1016/j.marpolbul.2007.05.022

Barreiro, M., 2010. Influence of ENSO and the South Atlantic Ocean on climate predictability over Southeastern South America. Climate Dynamics 35, 1493-1508 https://doi.org/10.1007/s00382-009-0666-9 


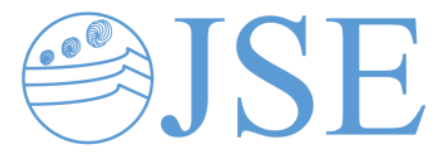

RESEARCH PAPER

Barros, V., Gonzalez, M., Liebmann, B., Camilloni, I., 2000. Influence of the South Atlantic convergence zone and South Atlantic Sea surface temperature on interannual summer rainfall variability in Southeastern South America. Theoretical and Applied Climatology 67(3-4),123-133.

Bergamino, L., Schuerch, M., Tudurí, A, Carretero, S., GarcíaRodríguez, F., 2017. Linking patterns of freshwater discharge and sources of organic matter within the Río de la Plata estuary and adjacent marshes. Marine and Freshwater Research 68(9), 1704-1715. https://doi.org/10.1071/MF16286

Bianchi, T.S. (eds.), 2007. Biogeochemistry of estuaries. Oxford University Press, Texas.

Bonachea, J., Bruschi, V., Hurtado, M., Forte, L., da Silva, M., Etcheverry, R., Cavallotto, J., Dantas, M., Pejon, O., Zuquette, L., Bezerra, M., Remondo, J., Rivas, V., Gómez-Arozamena, J., Fernandez, G., Cendrero, A., 2010. Natural and human forcing in recent geomorphic change; case studies in the Rio de la Plata basin. Science of the Total Environment, 408(13), 2674-2695. https://doi.org/10.1016/j.scitotenv.2010.03.004

Botto, F., Gaitán, E., Mianzan, H., Acha, M., Giberto, D., Schiariti, A., Iribarne, O., 2011. Origin of resources and trophic pathways in a large SW Atlantic estuary: An evaluation using stable isotopes. Estuarine, Coastal and Shelf Science 92, 70-77. https://doi.org/110.1016/j.ecss.2010.12.014

Bouillon, S., Connolly, R.M., Lee, S.Y., 2008. Organic matter exchange and cycling in mangrove ecosystems: recent insights from stable isotope studies. Journal of Sea Research 59, 44-58. https://doi.org/10.1016/j.seares.2007.05.001

Bueno, C., Brugnoli, E., Bergamino, L., Muniz, P., GarcíaRodríguez, F, Figueira, R., 2018. Anthropogenic and natural variability in the composition of sedimentary organic matter of the urbanised coastal zone of Montevideo (Río de la Plata). Marine Pollution Bulletin 126, 197-203. https://doi.org/10.1016/j.marpolbul.2017.11.009

Burone, L., Ortega, L., Franco-Fraguas, P., de Mahiques, M., García-Rodriguez, F., Venturini, N., Marin, Y., Brugnoli, E., Nagai, R., Muniz, P., Bícego, M., Figueira, R., Salaroli, A., 2013. A multiproxy study between the Río de la Plata and the adjacent South-western Atlantic inner shelf to assess the sediment footprint of river vs. marine influence. Continental Shelf Research 55,141-154. https://doi.org/10.1016/ j.csr.2013.01.003

Calliari, D., Gómez, M., Gómez, N., 2005. Biomass and composition of the phytoplankton in the Río de la Plata: largescale distribution and relationship with environmental variables during a spring cruise. Continental Shelf Research 25(2),197-210. https://doi.org/10.1016/j.csr.2004.09.009

Camilloni, I., 2005. Variabilidad y tendencias hidrológicas en la Cuenca del Plata. In: Barros, V., Menendez, A., Nagy, G (eds.), El cambio climático en el Río de la Plata. CIMA. Buenos Aires, pp. 21-31.

Canuel, E.A., Hardison, A.K., 2016. Sources, ages, and alteration of organic matter in estuaries. Annual Review of Marine Science 8, 409-434. https://doi.org/10.1146/annurev-marine122414-034058

Canuel, E.A., Zimmerman, A.R., 1999. Composition of particulate organic matter in the southern Chesapeake Bay: sources and reactivity. Estuaries and Coasts 22, 980-994.
Carpenter, S., Caraco, N., Correll, D., Howarth, R., Sharpley, A., Smith, V., 1998. Nonpoint pollution of surface waters with phosphorus and nitrogen. Ecological Applications 8(3), 559568.

Cavallotto, J., Violante, R., 2005. Geología y Geomorfología del Río de la Plata. In: de Barrio, R., Etcheverry, R. O., Caballé, M. F., Llambías, E. (eds.), Geología y recursos minerales de la Provincia de Buenos Aires. Relatorio XVI Congreso Geológico Argentino, La Plata, pp. 237-253.

Cavallotto, J., 2002. Evolución holocena de la llanura costera del margen sur del Río de la Plata. Revista de la Asociación Geológica Argentina 57(4), 376-388.

Cloern, J.E., Canuel, E.A., Harris, D., 2002. Stable carbon and nitrogen isotope composition of aquatic and terrestrial plants of the San Francisco Bay estuarine system. Limnology and Oceanography 47

713-729. https://doi.org/10.4319/lo.2002.47.3.0713

Codignotto, J., Kokot, R., 2005. Geología y geomorfología. In: Barros V., Menendez A., Nagy, G.(eds.), El cambio climático en el Río de la Plata. CIMA. Buenos Aires, pp. 21:31.

Dean, W.E., Arthur, M.A., Claypool, G.E., 1986. Depletion of 13C in Cretaceous marine organic matter: source, diagenetic or environmental signal? Marine Geology. 70, 119-157. https://doi.org/10.1016/0025-3227(86)90092-7

de Falco, G., Magni, P., Teräsvuori, L., Matteucci, G., 2004. Sediment grain size and organic carbon distribution in the Cabras lagoon (Sardinia, western Mediterranean). Chemistry and Ecology 20(1), 367-377. https://doi.org/10.1080/02757540310001629189

de Jonge, V.N., Elliott, M., Orive, E., 2002. Causes, historical development, effects and future challenges of a common environmental problem: eutrophication. Hydrobiologia 475(476), 1-19. https://doi.org/10.1023/A:1020366418295

de Mahiques, M., Figueira, R., Salaroli, A., Alves, D., Gonçalves, C., 2013. 150 years of anthropogenic metal input in a Biosphere Reserve: the case study of the Cananéia-Iguape coastal system, Southeastern Brazil. Environmental earth sciences 68(4), 10731087. https://doi.org/10.1007/s12665-012-1809-6

de Souza, V., Rodrigues, K., Pedroza, E., de Melo, R., de Lima, V., Hazin, C., de Almeida, M., do Nascimento, R., 2012. Sedimentation Rate and ${ }^{210} \mathrm{~Pb}$ Sediment Dating at Apipucos Reservoir, Recife, Brazil. Sustainability 4, 2419-2429. https://doi.org/10.3390/su4102419

Dehairs, F., Rao, G.G., Chandra Mohan, P., Raman, A.V., Marguillier, S., Hellings, L., 2000. Tracing mangrove carbon in suspended matter and aquatic fauna of the Gautami-Godavari Delta, Bay of Bengal (India). Hydrobiologia 431, 225-241. https://doi.org/10.1023/A:1004072310525

Depetris, P., Kempe, S., Latif, M., Mook, W., 1996. ENSO controlled flooding in the Paraná River (1904-1991). Naturwissenschaften 83, 127-129.

Derisio, C., Braverman, M., Gaitán, E., Hozbor, C., Ramírez, F., Carreto, J., Botto, F., Gagliardini, D., Acha, M., Mianzan, H., 2014. The turbidity front as a habitat for Acartia tonsa (Copepoda) in the Río de la Plata, Argentina-Uruguay. Journal https://doi.org/10.1016/j.seares.2013.04.019

Fossati, M., Santoro, P., Mosquera, R., Martínez, C., Ghiardo, F., Ezzatti, P., Pedocchi, F., Piedra-CuevaI, I., 2014. Dinámica de of Sea Research 85, 197-204. 
flujo, del campo salino y de los sedimentos finos en el Río de la Plata. Revista Iberoamericana del Agua 1(1), 48-63.

Framiñan, M.B., Valle-Levinson, A., Sepulveda, H.H., Brown, O.B., 2008. Tidal variations of flow convergence, shear, and stratification at the Rio de la Plata estuary turbidity front. Journal of Geophysical Research 113, 1-17. https://doi.org/10.1029/2006JC004038

Framiñan, M., Etala, M., Acha, E., Guerrero, R., Lasta, C., Brown, O. 1999. Physical characteristics and processes of the Río de la Plata estuary. In: Perillo G., Piccolo M., Pino M. (eds.), Estuaries of South America. Their Geomorphology and Dynamics. Springer-Verlag, Berlin, Cap VII, pp161-194.

Framiñan, M., Brown, O., 1996. Study of the Río de la Plata turbidity front, part 1: spatial and temporal distribution. Continental Shelf Research 16 (10), 1259-1282. https://doi.org/10.1016/0278-4343(95)00071-2

FREPLATA, 2004. Análisis Diagnóstico Transfronterizo del Río de la Plata y su Frente Marítimo. Documento Técnico. Protección Ambiental del Río de la Plata y su Frente Marítimo Proyecto. Proyecto PNUD/GEF/RLA/99/G31

Fry, B., Gace, A., McClelland, J., 2003. Chemical indicators of anthropogenic nitrogen-loading in four Pacific estuaries. Pacific Science 57(1), 77-101. https://doi.org/10.1353/ psc.2003.0004

Fry, B., Sherr, E.B., 1984. $\delta^{13} \mathrm{C}$ measurements as indicators of carbon flow in marine and freshwater ecosystems. Contributions in Marine Science 27, 13-47.

Gao, J., Wang, Y., Pan, S., Zhang, R., Li, J., Bai, F., 2008. Spatial distributions of organic carbon and nitrogen and their isotopic compositions in sediments of the Changjiang Estuary and its adjacent sea area. Journal of Geographical Sciences 18(1), 4658. https://doi.org/10.1007/s11442-008-0046-0

García-Rodríguez, F., Brugnoli, E., Muniz, P., Venturini, N., Burone, L., Hutton, M., Rodríguez, A., Pita, A., Kandratavicius, M.N., Pérez, L., Verocai, J., 2014. Warm-phase ENSO events modulate the continental freshwater input and the trophic state of sediments in a large South American estuary. Marine and Freshwater Research 65(1), 1-11. https://doi.org/10.1071/MF13077

Garreaud, R., Vuille, M., Compagnucci, R., Marengo, J., 2009. Present-day south American climate. Palaeogeography, Palaeoclimatology, Palaeoecology 281(3), 180-195. https://doi.org/10.1016/j.palaeo.2007.10.032

Giberto, D.A., Bremec, C.S., Acha, E.M., Mianzan, H., 2004. Largescale spatial patterns of benthic assemblages in the SW Atlantic: the Río de la Plata. Estuarine, Coastal and Shelf Science 61, 1-13. https://doi.org/10.1016/j.ecss.2004.03.015

Goñi, M.A., Voulgaris, G., Kim, Y.H., 2009. Composition and fluxes of particulate organic matter in a temperate estuary (Winyah Bay, South Carolina, USA) under contrasting physical forcings. Estuarine, Coastal and Shelf Science 85, 273-291. https://doi.org/10.1016/j.ecss.2009.08.013

Goñi, M.A., Teixeira, M.J., Perkey, D.W., 2003. Sources and distribution of organic matter in a river-dominated estuary (Winyah Bay, SC, USA). Estuarine, Coastal and Shelf Science 57, 1023-1048. https://doi.org/10.1016/S02727714(03)00008-8
Hammer, Ø., Harper, D., Ryan, P., 2001. Past: Paleontological Statistics Software Package for education and data analysis. Palaeontologia Electronica 4(1), 4-9.

INA-FREPLATA, 2012. Antecedentes sobre calidad del agua del Río de la Plata. Componente B: Modelación de Calidad del Agua, Análisis de Antecedentes. Proyecto PNUD ARG/09/G46 - FREPLATA II. Instituto Nacional del Agua - Laboratorio de Hidráulica (Argentina).

Kuramoto, T., Minagawa, M. 2001. Stable carbon and nitrogen isotopic characterization of organic matter in a mangrove ecosystem on the southwestern coast of Thailand. Journal of Oceanography 57 (4), 421-443. https://doi.org/10.1023/ A:1021232132755

Lamb, A., Wilson, G., Leng, M.J., 2006. A review of coastal palaeoclimate and relative sea-level reconstructions using $\delta^{13} \mathrm{C}$ and $\mathrm{C} / \mathrm{N}$ ratios in organic material. Earth-Science Reviews, 75(1), 29-57. https://doi.org/10.1016/j.earscirev.2005.10.003

Lara, R., Alder, V., Franzosi, C., Kattner, G., 2010. Characteristics of suspended particulate organic matter in the southwestern Atlantic: influence of temperature, nutrient and phytoplankton features on the stable isotope signature. Journal of Marine Systems $\quad 79(1), \quad 199-209$. https://doi.org/10.1016/j.jmarsys.2009.09.002

Liu, D., Li, X., Eméis, K. C., Wang, Y., Richard, P., 2015. Distribution and sources of organic matter in surface sediments of Bohai Sea near the Yellow River Estuary, China. Estuarine, Coastal and Shelf Science 165, 128-136. https://doi.org/10.1016/j.ecss.2015.09.007

Lüning, S., Gałka, M., Bamonte F.P., García-Rodríguez, F., Vahrenholt, F., 2018. The Medieval Climate Anomaly in South America. Quaternary International. https://doi.org/10.1016/ j.quaint. 2018.10.041

Mantua, N., Hare, S., Zhang, Y., Wallace J., Francis, R., 1997. A Pacific interdecadal climate oscillation with impacts on salmon production. Bulletin of the American Meteorological Society 78 (6), 1069-1079.

Marchese, M., Saigo, M., Zilli, F., Capello, S., Devercelli, M., Montalto, L., Paporelloa, G., Wantzen, K., 2014. Food webs of the Paraná River floodplain: Assessing basal sources using stable carbon and nitrogen isotopes. Limnologica-Ecology and Management of Inland Waters 46, 22-30. https://doi.org/10.1016/j.limno.2013.11.004

Marrero, A., Tudurí, A., Pérez, L., Cuña, C., Muniz, P., Figueira, R.C.L., Mahiques, M., Ferreira, P.A.L., Pittauerová, D., Hanebuth, T., García-Rodríguez, F., 2014. Cambios históricos en el aporte terrígeno de la cuenca del Río de la Plata sobre la plataforma interna uruguaya. Latin American Journal of Sedimentology and Basin Analysis 21(2), 165-179.

Martins, V., Figueira, R., França, E., Ferreira, P., Martins, P., Santos, J., Alveirinho, J., Laut, L., Monge, A., da Silva, J., Rocha, F., 2012. Sedimentary processes on the NW Iberian Continental Shelf since the Little Ice Age. Estuarine, Coastal and Shelf Science 102, 48-59. https://doi.org/10.1016/j.ecss.2012.03.004

Mauas, P., Flamenco, E., Buccino, A., 2008. Solar forcing of the stream flow of a continental scale South American river. Physical Review Letters $101 \quad$ (16), 168501. https://doi.org/10.1103/PhysRevLett.101.168501. 
Mechoso, C.R., Iribarren, G.P., 1992. Streamflow in southeastern South America and the southern oscillation. Journal of Climate 5 (12), 1535-1539.

Méndez, S., Ferrari, G., 2002. Floraciones algales nocivas en Uruguay: antecedentes, proyectos en curso y revisión de resultados. In: Sar, E.A., Ferrario, M.E., Reguera, B. (eds.), Floraciones algales nocivas en el Cono Sur Americano, pp. 271-288.

Meyers, P., 2003. Applications of organic geochemistry to paleolimnological reconstructions: a summary of examples from the Laurentian Great Lakes. Organic Geochemistry 34(2), 261-289. https://doi.org/10.1016/S01466380(02)00168-7

Meyers, P., 1994. Preservation of elemental and isotopic source identification of sedimentary organic matter. Chemical Geology 114 (3-4), 289-302.

Nagy, G.J., Gómez-Erache, M., López, C., Perdomo, A., 2002. Distribution patterns of nutrients and symptoms of eutrophication in the Rio de la Plata River Estuary System. Hydrobiologia 1 (475-476), 125-139.

Paerl, H., 2006. Assessing and managing nutrient-enhanced eutrophication in estuarine and coastal waters: Interactive effects of human and climatic perturbations. Ecological Engineering 26(1),

40-54. https://doi.org/10.1016/j.ecoleng.2005.09.006

Parnell, A.C., Inger, R., Bearhop, S., Jackson, A.L., 2010. Source partitioning using stable isotopes: coping with too much variation. PLoS ONE 5(3): e9672. https://doi.org/10.1371/journal.pone.0009672

Pérez, P., García-Rodríguez, F., Hanebuth, T., 2017. Paleosalinity changes in the Río de la Plata Estuary and on the adjacent Uruguayan Continental Shelf over the past 1200 years: an approach using diatoms as a proxy. In: Weckström, K. Saunders, K.M., Gell, P.A., Skilbeck, C.G. (eds.). Applications of Paleoenvironmental Techniques in Estuarine Studies. Springer, Dordrecht, pp. 529-549.

Pérez, L., García-Rodríguez, F., Hanebuth, T.J.J., 2016. Variability in terrigenous sediment supply offshore of the Río de la Plata (Uruguay) recording the continental climatic history over the past 1200 years. Climate of the Past 12, 623-634. https://doi.org/10.5194/cp-12-623-2016

Peters, K., Sweeney, R., Kaplan, I., 1978. Correlation of carbon and nitrogen stable isotope ratios in sedimentary organic matter. Limnology and Oceanography 23(4), 598-604.

Piedra-Cueva, I., Fossati, M., 2007. Residual currents and corridor of flow in the Rio de la Plata. Applied Mathematical Modelling, 31(3), 564-577. https://doi.org/10.1016/j.apm.2005.11.033

Piovano, E.L., Ariztegui, D., Bernasconi, S.M., Mckenzie, J.A., 2004. Stable isotopic record of hydrological changes in subtropical Laguna Mar Chiquita (Argentina) over the last 230 years. The Holocene 14, 525-535. https://doi.org/10.1191/ 0959683604hl729rp

\section{RESEARCH PAPER}

Pittau, M., Sarubbi, A., Menéndez, A., 2001. Análisis del avance del frente del delta del Río Paraná. INA, Laboratorio de Hidráulica. Buenos Aires.

Sánchez-Cabeza, J.A., Díaz-Asencio, M., Ruiz-Fernández, A.C. (eds.), 2012. Radiocronología de sedimentos costeros utilizando ${ }^{210} \mathrm{~Pb}$ : modelos, validación y aplicaciones. Organismo Internacional de Energía Atómica, Centro Internacional de Viena.

Savage, C., 2005. Tracing the influence of sewage nitrogen in a coastal ecosystem using stable nitrogen isotopes. AMBIO: A Journal of the Human Environment 34(2), 145-150. https://doi.org/10.1579/0044-7447-34.2.145

Schweizer, M., Fear, J., Cadisch, G., 1999. Isotopic $\left({ }^{13} \mathrm{C}\right)$ fractionation during plant residue decomposition and its implications for soil organic matter studies. Communications in Mass Spectrometry 13, 1284-1290.

Serna, A., Pätsch, J., Dähnke, K., Wiesner, M., Hass, H., Zeiler, M., Hebbeln, D., Emeis, K., 2010. History of anthropogenic nitrogen input to the German Bight/SE North Sea as reflected by nitrogen isotopes in surface sediments, sediment cores and hindcast models. Continental Shelf Research 30(15), 16261638. https://doi.org/10.1016/j.csr.2010.06.010

Simionato, C.H., Moreira, D., Fossatti, M. (eds), 2011. Estudio de la dinámica hidro-sedimentológica del Rio de La Plata: Observación y modelación numérica de los sedimentos finos. Proyecto FREPLATA LA 99/G31

Sokal, R.R., Rohlf, F.J., (eds.), 2012. Biometry: The Principles and Practice of Statistics in Biological Research. 4th edition. W.H. Freeman and Company New York.

Sweeney, R., Kaplan, I., 1980. Natural abundances of ${ }^{15} \mathrm{~N}$ as a source indicator for near-shore marine sedimentary and dissolved nitrogen. Marine Chemistry 9(2), 81-94.

Venturini, N., Bícego, M., Taniguchi, S., Sasaki, S., GarcíaRodríguez, F., Brugnoli, E., Muniz, P., 2015. A multi-molecular marker assessment of organic pollution in shore sediments from the Río de la Plata Estuary, SW Atlantic. Marine Pollution Bulletin 91, 461-475. https://doi.org/10.1016/j.marpolbul. 2014.06.056

Wilson, G., Lamb, A., Leng, M., Gonzalez, S., Huddart, D., 2005. $\delta^{13} \mathrm{C}$ and $\mathrm{C} / \mathrm{N}$ as potential coastal palaeoenvironmental indicators in the Mersey Estuary, UK. Quaternary Science Reviews 24(18), 2015-2029. https://doi.org/10.1016/ j.quascirev. 2004.11.014

Wissel, B., Fry, B. 2005. Tracing Mississippi River influences in estuarine food webs of coastal Louisiana. Oecologia 144, 659672. https://doi.org/10.1007/s00442-005-0119-Z

Yu, F., Zong, Y., Lloyd, J.M., Huang, G., Leng, M.J., Kendrick, C., Lamb, A.L., Yim, W.W.S., 2010. Bulk organic $\delta^{13} \mathrm{C}$ and $\mathrm{C} / \mathrm{N}$ as indicators for sediment sources in the Pearl River delta and estuary, southern China. Estuarine, Coastal and Shelf Science 87, 618-630. https://doi.org/10.1016/j.ecss.2010.02.018 